\title{
Assessing Profit Shifting in Lithuanian Firms
}

\author{
Egidijus Kundelis ${ }^{1, *}$, Renata Legenzova ${ }^{2}$, and Julijonas Kartanas ${ }^{1}$ \\ ${ }^{1}$ ISM University of Management and Economics, Faculty of Economics, Arkliu st. 18, LT-01305, \\ Vilnius, Lithuania \\ ${ }^{2}$ Vytautas Magnus University, Faculty of Economics and Management, S. Daukanto st. 28, LT-44246, \\ Kaunas, Lithuania
}

\begin{abstract}
.
Research background: Multinational enterprises (MNEs) employ tax avoidance by ability to use differences in tax systems of various countries to successfully incur effective tax rate that is lower than the statutory one. Literature analysis revealed that previous research rarely concentrated on profit shifting practices in small economies. It mostly covered large countries (USA, Germany) or regions (e.g. Europe). Research on Lithuania, as a small open economy characterized by lower corporate income tax rates, is a relevant case for the analysis.

Purpose of the article: The purpose of the article is to assess profit shifting via transfer mispricing in Lithuanian companies.

Methods: Regression analysis with fixed effects was applied to a sample of 3,563 Lithuanian companies for the period of 2010-2018. The data was retrieved from Amadeus database.

Findings \& Value added: The results of testing profit shifting channel transfer mispricing - showed that tax incentives significantly affect earnings of MNEs in the sample while results of domestic firms are puzzling. Earnings of multinationals in the sample are strongly affected by statutory tax rate difference between the subsidiary operating in Lithuania and the parent company in a foreign country. Such results may imply that in small economies like Lithuania (characterized by lower tax rates and lower tax avoidance costs) profit shifting via transfer mispricing is used by MNEs as a channel of corporate tax avoidance.
\end{abstract}

Keywords: profit shifting; transfer pricing; multinational enterprise

JEL Classification: $H 26$; $G 32$

\section{Introduction}

Tax avoidance is the reallocation of profits by multinational enterprises (MNEs) in response to tax differences between countries, with the aim to minimize the global tax costs. Actions taken when doing so are called base erosion and profit shifting (BEPS). They cause an annual loss in global tax revenue between $\$ 100$ and 650 billion [1]. Income

\footnotetext{
*Corresponding author: egidijus.kundelis@stud.ism.lt
} 
taxation of corporations being one of the major ways to collect capital-based revenues makes BEPS activities a serious issue for governments to consider. Taxing domestic companies is usually straight forward, but process can get complicated when talking about corporations operating across borders. Inconsistencies in tax systems of countries create opportunities to be exploited. Any kind of tax avoidance doesn't coincide with governments' goals of tax revenue maximization or general efficiency and fairness. Budget deficiency results in limited spending possibilities, that could otherwise contribute to the growth of economy, or greater wellbeing of society. Additional tax avoidance countermeasures further complicate the tax system and increase compliance costs of the companies. Also, when some companies avoid taxes, it shifts the burden to others. Peer firms, that follow the law and fairly pay taxes without using loopholes in the tax system, are naturally put into a worse competitive position. Still, multinational enterprises (MNE) have greater opportunities to perform tax planning than domestic companies.

From microeconomics perspective, companies have profit maximization as their main financial goal, so managers aim to increase earnings for shareholders by reducing the cost of taxation. Thus, lower effective tax rate can be directly associated with higher shareholder value, and it might drive companies to engage in BEPS activities.

MNEs can realize BEPS through different channels [2]. Profit shifting via transfer mispricing is the most widely used BEPS channel [3] and was chosen as a subject for deeper analysis. Transfer prices are the prices charged for transactions between related parties. Tax laws prescribe that an account of each multinational subsidiary terminates at the border (separate accounting concept), therefore, each subsidiary's prices should be established at arm's length. But there can exist a wide range of arm's-length prices for the same transaction or there may even be no "correct" arms-length price, especially when a comparable transaction does not exist for unrelated parties. Therefore, MNEs can choose charging artificially low or high prices for sales between related parties in high-tax and lowtax jurisdictions, thereby shifting profits and reducing their overall tax liabilities. Empirical studies support the above and document evidence that subsidiaries of MNEs are engaged in transfer pricing manipulation activities, shifted profits from high-tax to low-tax countries and reduced aggregated effective tax rate [e.g. 4].

Furthermore, number of empirical studies conducted in different countries support the substantial tax impact on company's transfer mispricing activities, but report differences in its magnitude. Some authors also claim that corporate tax avoidance via transfer pricing is limited due to institutional measures imposed (transfer pricing rules, transfer pricing documentation requirements, penalties for non-compliance) and high implementation costs. Yet, a majority of the previous empirical research on transfer mispricing covered large countries (USA, Germany, UK, France, Denmark, South Africa) or regions (e.g. Europe, OECD countries) leaving a gap in research on small economies characterized by lower corporate income tax rates, which makes countries such as Lithuania a relevant case for the analysis. Our previous research [e.g. 5] assessed the impact of base erosion and profit shifting on multinational corporations' subsidiaries' performance in the Baltic countries for the period of 2007-2015. The research revealed that Baltic countries' tax differentials between multinational corporations' parent and subsidiary countries might have a significant impact on the subsidiary's financial performance. When the tax rate differences between Baltic and the foreign countries decrease by $1 \%$, reported profits in Baltic countries increase by $2.3 \%$, indicating profit-shifting behaviour.

The article is aiming to assess the evidence of corporate tax avoidance across both domestic firms and subsidiaries of MNEs operating in Lithuania. We argue, that due to specifics of small economies like Lithuania (lower tax rates and low tax avoidance costs) corporate tax avoidance of subsidiaries of multinational corporations occurs via profit shifting channel of transfer mispricing. 
The research used regression analysis with fixed effects and applied it to a sample of 3,563 Lithuanian companies retrieved from Amadeus database for the period of 2010-2018. As for Lithuanian companies firm-level information on intra-firm transfer prices was unavailable, this paper followed previous literature by choosing the indirect method of testing profit shifting via transfer pricing manipulation and assessed if the tax incentives reduce firms' pre-tax profits.

\section{Literature review}

Profit shifting via transfer mispricing. Generally, transfer prices are the prices charged for transactions between related parties. MNEs can choose charging artificially low or high prices for sales between related parties in high-tax and low-tax jurisdictions, thereby shifting profits and reducing their overall tax liabilities. [6] were one of the first to find that US multinational firms in 1982 reported significantly higher (pre-tax) profits in low-tax countries than in high-tax countries after controlling for labour, capital and local economic conditions. There have been several subsequent studies of this type by $[7,8,9]$. For example, [8] show that a $1 \%$ lower tax rate differential in absolute terms is related to $1.43 \%$ (1.43 semi-elasticity) increased profitability of European firms and their estimated effect is smaller than the one reported by [6] - 6.3\% (6.3 semi-elasticity). The key methodological reason for such a significant difference might be related to the use of firm level data by [8] and the employment of firm fixed effects. Furthermore, it is worth noting that both [6] and [8] used cross-sectional data (1982 and 1999 respectively) while recent studies mostly use panel data, giving more reliable estimations.

In contrast to the previous studies, [10] analysed the impact of corporate taxes on both pre- and post-tax profitability using a 2003-2011 panel dataset of European subsidiaries. They found that a $1 \%$ decrease in the tax rate increases post-tax profitability (excluding financial profits) by up to $0.06 \%$. Furthermore, they indicate that financial profits and losses are particularly responsive to taxes. Total increase up to $0.11 \%$ percentage points of post-tax profitability (including financial profits) indicates that a large part of profit shifting (i.e. difference of $0.05 \%$ of post-tax profitability) takes place via debt shifting.

Using panel data of European firms from 1999 to 2009 and controlling for affiliate location, [11] found even smaller effects than those reported by [8]. Their findings suggest that $1 \%$ higher tax rate is related to $0.4 \%$ reduced profitability.

Based on mixed research outcomes, [12] suggested that the BEPS problem might be overstated. He claims that the economic consequences of corporate tax avoidance cannot be material considering that CIT amounts to $8-10 \%$ of the total tax revenues of most economies in OECD countries. Only a fraction of CIT revenues is paid by multinational companies, and only $2-4 \%$ of profits of multinationals are shifted to low-tax countries. Tax enforcement regulation introduced by governments results in substantial tax planning costs, which restricts tax avoidance.

\section{Methods}

Models. Regression analysis with fixed effects was applied to test profit shifting via transfer mispricing across two samples of firms: domestic and MNEs. The model can be summarized in equation (1):

$$
\operatorname{LnEBT}_{f, t}=\beta_{0}+\beta_{1} \text { Tax }_{f, t}+\beta_{k} \text { Firm_controls }_{f, t}+\beta_{j} \text { Industry_controls }_{i, t}+\varepsilon_{f, t}
$$

Letter $f$ denotes each individual firm, $i$ - industry, $t$ - year. Constant term $\beta_{0}$ is used to represent part of dependent variable that can't be explained by independent variables. A set 
of Firm and Industry control variables are employed, where $k$ and $j$ identify each separate variable. Lastly, error term $\varepsilon_{f, t}$ represents stochastic variation in firm's dependent variable because of omitted variables and measurement errors. The main dependant variable in the model is EBT. Natural logarithmic values are used to reduce the variance in observations and make impact of outliers less severe.

Independent variable. The main independent variable used in this research is a tax measure, which has several proxies. Previous research [e.g. 5] most commonly focused on statutory tax rate (STR) as the key explanatory variable, but in Lithuania during the research period the STR was constantly equal to $15 \%$. In theory, effective tax rate (ETR) should have statistically stronger representation, compared to statutory rate, as ETR depends on characteristics of each company and is much more dynamic over time. In our model ETR is defined as tax expenses divided by earnings before taxes. Specifically, annual dynamic average of ETR3 over the past 3 years is chosen to provide more robust results. Researchers [e.g. 4, 9] prove higher level of profits to be strongly related with lower ETR. Hence, the authors expect ETR coefficient sign to be negative. Moreover, standard deviation of ETR is also examined to represent sensitivity of firm's operations to taxation. Higher instability of ETR indicates higher volatility, which can be associated with higher risk or higher levels of profits. So, expected effect of ETR volatility on EBT is positive. Metric of book tax difference (BTD) was also used as independent variable and calculated by subtracting tax base (calculated as tax expenses accounted in income statement divided by the statutory tax rate) from reported EBT (accounting base/book profits) and dividing result by sales revenues. It should provide more accurate representation since it reflects long-run and short-run tax differences more consistently, can be used during tax loss years and is proportional with rather stable firm-level indicator - assets. There's higher probability of tax planning if a firm has higher BTDs, so, expected effect on EBT is positive. However, the effect of BTD should be considered together with ETR3 effect to mitigate the impact of earning management practices. Lastly, cross-country tax differential (TaxDiff) was calculated, which should represent incentive to shift profits (via transfer mispricing) between multinational parent located in foreign country and its subsidiary located in Lithuania. In this setting much narrower sample is used by selecting only local subsidiaries of MNEs, meaning that all domestic firms are excluded from the sample.

Control variables. Two sets of control variables: based on firm-level and industry-level controls are included (Table 1). These are constructed mainly according to methodology of [11].

Table 1. Summary of control variables.

\begin{tabular}{|c|c|c|c|c|}
\hline Variable & Specification & Abbreviation & Function & $\begin{array}{c}\text { Expected } \\
\text { Effect }\end{array}$ \\
\hline \multirow{7}{*}{$\begin{array}{c}\text { Firm- } \\
\text { level }\end{array}$} & Size & Assets & $\ln ($ Assets $)$ & + \\
\cline { 2 - 5 } & Size growth & Growth & $\frac{\ln (\text { Assets })_{t}}{\ln (\text { Assets })_{t-1}}$ & + \\
\cline { 2 - 5 } & $\begin{array}{c}\text { Number of } \\
\text { employees }\end{array}$ & Worker & $\ln ($ Employees $)$ & + \\
\cline { 2 - 5 } & Leverage & TDR & $\frac{\text { Short term debt }+ \text { Long term debt }}{\text { Assets }}$ & + \\
\cline { 2 - 5 } & Tangibility & Tangible & $\frac{\text { Fixed assets }}{\text { Assets }}$ & + \\
\cline { 2 - 5 } & Intangible assets & Intangible & $\frac{\text { Intangible assets }}{\text { Assets }}$ & + \\
\cline { 2 - 5 } & Liquidity & Liquidity & $\frac{\text { Current assets }}{\text { Current liabilities }}$ & + \\
\hline
\end{tabular}




\begin{tabular}{|c|c|c|c|c|}
\hline & $\begin{array}{l}\text { Administration } \\
\text { costs }\end{array}$ & AdminCost & $\frac{\text { Gross profit }- \text { EBIT }}{\text { Revenue }}$ & $+/-$ \\
\hline & Business risk & FinRisk & Altman Z-score & - \\
\hline \multirow{2}{*}{$\begin{array}{l}\text { Industry- } \\
\text { level }\end{array}$} & $\begin{array}{l}\text { Median firm size } \\
\text { (asset) growth }\end{array}$ & \multicolumn{2}{|r|}{ ind_Growth } & $+1-$ \\
\hline & $\begin{array}{l}\text { Median firm } \\
\text { leverage }\end{array}$ & \multicolumn{2}{|c|}{$\begin{array}{l}\text { ind_Leverage or ind_Liabilities } \\
\text { (total; short; long) }\end{array}$} & + \\
\hline
\end{tabular}

Data sample. The data for the period of 2010-2018 was retrieved from the Amadeus database. It included various annual firm-level financial data accounted at book-values, as well as ownership and industry information. The final data sample represented 3,563 crosssectional units over 9 time periods or 32,067 observations. The sample was split into domestic firms and subsidiaries of MNEs.

\section{Results}

Results of profit shifting model. Table 2 presents the results of profit shifting model via transfer mispricing activities.

Table 2. Regression results of profit shifting via transfer mispricing.

\begin{tabular}{|c|c|c|c|c|c|c|c|}
\hline $\begin{array}{l}\text { Sample } \\
\text { (owner) }\end{array}$ & Local & Foreign & Local & Foreign & Local & Foreign & Foreign \\
\hline $\begin{array}{c}\text { Tax } \\
\text { variable }\end{array}$ & \multicolumn{2}{|c|}{ ETR3 } & \multicolumn{2}{|c|}{ stdevETR } & \multicolumn{2}{|c|}{ BTD } & TaxDiff \\
\hline const & $\begin{array}{c}- \\
2.1927^{* *} \\
*\end{array}$ & -0.7954 & $\begin{array}{c}- \\
2.8462 * * \\
*\end{array}$ & -0.439 & $\begin{array}{c}- \\
2.9883 * * \\
*\end{array}$ & -0.9163 & $\begin{array}{c}- \\
1.6882 * *\end{array}$ \\
\hline $\begin{array}{c}\text { Tax } \\
\text { variable }\end{array}$ & -0.0862 & $\begin{array}{c}- \\
0.0724 * * \\
*\end{array}$ & $\begin{array}{c}- \\
0.5981 * * \\
*\end{array}$ & $\begin{array}{c}- \\
0.0737 * * \\
*\end{array}$ & $\begin{array}{c}1.4642^{* *} \\
*\end{array}$ & $0.7904 * *$ & $-2.304^{*}$ \\
\hline Assets & $\begin{array}{c}0.8658^{* *} \\
*\end{array}$ & $\begin{array}{c}0.8882 * * \\
*\end{array}$ & $\begin{array}{c}0.9565^{* *} \\
*\end{array}$ & $\begin{array}{c}0.8398 * * \\
*\end{array}$ & $\begin{array}{c}0.9582 * * \\
*\end{array}$ & $\begin{array}{c}0.8808^{* *} \\
*\end{array}$ & $\begin{array}{c}0.8978^{* *} \\
*\end{array}$ \\
\hline Growth & $\begin{array}{c}3.7788^{* *} \\
*\end{array}$ & 1.1723 & $\begin{array}{c}3.8081 * * \\
*\end{array}$ & 1.1195 & $\begin{array}{c}3.6152^{* *} \\
*\end{array}$ & 0.2108 & 0.2315 \\
\hline Workers & 0.0853 & -0.1182 & 0.0578 & -0.0865 & 0.0673 & -0.0594 & -0.0007 \\
\hline TDR & $\begin{array}{c}- \\
0.5822 * * \\
*\end{array}$ & $\begin{array}{c}- \\
0.7198 * * \\
*\end{array}$ & $\begin{array}{c}- \\
0.5731^{* *} \\
*\end{array}$ & $\begin{array}{c}- \\
0.7153^{* *} \\
*\end{array}$ & $\begin{array}{c}- \\
0.6119^{* *} \\
*\end{array}$ & $\begin{array}{c}- \\
0.8104^{* *} \\
*\end{array}$ & $\begin{array}{c}- \\
0.8354 * * \\
*\end{array}$ \\
\hline Tangible & -0.2813 & $\stackrel{-}{0.6921 * *}$ & -0.1716 & $\begin{array}{c}- \\
0.6668 * *\end{array}$ & -0.2504 & $\begin{array}{c}- \\
0.7809 * * \\
*\end{array}$ & $\stackrel{-}{-} 0.6025^{* *}$ \\
\hline Intangible & -0.6132 & $\begin{array}{c}- \\
1.8605^{* *} \\
*\end{array}$ & -0.9343 & $\begin{array}{c}- \\
1.791 * * *\end{array}$ & -0.63 & $\begin{array}{c}- \\
1.7567 * * \\
*\end{array}$ & $\begin{array}{c}- \\
1.3594 * *\end{array}$ \\
\hline Liquidity & $\begin{array}{c}- \\
0.0051^{* *} \\
*\end{array}$ & $-0.05 * * *$ & $\begin{array}{c}- \\
0.0055^{* *} \\
*\end{array}$ & $\begin{array}{c}- \\
0.0466^{* *} \\
*\end{array}$ & $\begin{array}{c}- \\
0.0054 * * \\
*\end{array}$ & $\begin{array}{c}- \\
0.0453 * * \\
*\end{array}$ & 0.0008 \\
\hline$\underset{t}{\operatorname{Admin} C o s}$ & $\begin{array}{c}- \\
1.4699 * * \\
*\end{array}$ & $\begin{array}{c}- \\
2.1116^{* *} \\
*\end{array}$ & $\begin{array}{c}- \\
1.5718^{* *} \\
*\end{array}$ & $\begin{array}{c}- \\
2.5387 * * \\
*\end{array}$ & $\begin{array}{c}- \\
1.4524 * * \\
*\end{array}$ & $\begin{array}{c}- \\
2.3661 * * \\
*\end{array}$ & $\begin{array}{c}- \\
2.4885^{* *} \\
*\end{array}$ \\
\hline FinRisk & $\begin{array}{c}0.1744 * * \\
*\end{array}$ & $\begin{array}{c}0.1518^{* *} \\
*\end{array}$ & $\begin{array}{c}0.1783 * * \\
*\end{array}$ & $\begin{array}{c}0.1438 * * \\
*\end{array}$ & $\begin{array}{c}0.1686^{* *} \\
*\end{array}$ & $\begin{array}{c}0.1392^{* *} \\
*\end{array}$ & $\begin{array}{c}0.1338^{* * *} \\
*\end{array}$ \\
\hline ind_Growt & 4.2916 & 5.3687 & $6.5643^{*}$ & 7.8722 & $7.4337 * *$ & 7.2129 & 6.3089 \\
\hline
\end{tabular}




\begin{tabular}{|c|c|c|c|c|c|c|c|}
\hline $\mathrm{h}$ & & & & & & & \\
\hline ind_TDR & $1.121^{* * *}$ & -0.1661 & $\begin{array}{c}- \\
1.2224 * * \\
*\end{array}$ & -0.3065 & $\begin{array}{c}- \\
1.0348 * * \\
*\end{array}$ & -0.2686 & -0.2805 \\
\hline R-squared & 0.8317 & 0.8604 & 0.8281 & 0.847 & 0.8246 & 0.8491 & 0.8346 \\
\hline
\end{tabular}

Note: * denotes significance at $10 \%$ (p-value $<0.1) ; * *$ significance at $5 \%(\mathrm{p}$-value $<0.05)$; and $* * *$ significance at $1 \%(\mathrm{p}$-value $<0.01)$; all estimations performed using fixed-effects.

Results show that all tax variables are significant for subsidiaries of MNEs. TaxDiff has a negative coefficient showing that higher parent country tax rate leads to higher earnings of subsidiaries of MNEs in Lithuania. ETR3 impacts foreign firms' EBT with a negative coefficient: firms that achieve lower effective tax rate have higher earnings before tax. This reassures the result of TaxDiff: tax avoidance leads to higher earnings of MNEs subsidiaries located in low-tax countries. Positive correlation of BTD and EBT suggests that tax planning leads to higher BTDs, which in turn is related with higher earnings. In line to ETR3 specification, BTD results suggests that multinationals may avoid taxes by shifting profits to subsidiaries in Lithuania.

In general, higher parent country tax rate (or higher tax differential, or lower subsidiary's effective tax rate) leads to increased earnings of subsidiary in Lithuania. Such findings are confirmed by [9] who found earnings of subsidiaries in lower-tax countries to be positively affected by tax difference with U.S. parent: if STR gap is wider by $1 \%$, subsidiary shows $0.5 \%$ higher profit rate. In our model, expressed numerically, $10 \%$ increase in the difference between STR of foreign parent and subsidiary in Lithuania leads to 0.23 increase in $\operatorname{lnEBT}$. LnEBT has median of 5.718 (or $€ 304.3$ thousand if logarithm removed). Hence, $10 \%$ increase in tax difference may explain $€ 78.7$ thousand increase in EBT - effects are very substantial. Altogether, the results indicate aggressive tax planning via transfer mispricing amongst sampled firms of foreign MNEs.

\section{Discussion and Conclusions}

Results of profit shifting via transfer mispricing assumption prove that earnings of multinationals in the sample are strongly affected by statutory tax rate difference between the subsidiary operating in Lithuania and the parent company in a foreign country. Based on median values, $10 \%$ increase in difference of statutory tax rates between host and parent countries explains 1.26 times higher pre-tax earnings of multinational subsidiary in Lithuania. This is in line with our previous research [5]. Estimated impact remained robust across few tax variable specifications. The results are in line with the empirical literature and practices applied by MNEs [13]. It can be assumed that in Lithuania due to low tax rates and lower tax avoidance costs, subsidiaries of MNEs may pursue corporate tax avoidance via transfer mispricing channel. MNEs may reallocate wealth from high- to lowtax country-based subsidiaries by overstating international transfers [9]. This supports antitax avoidance measures targeting transfer mispricing introduced by the OECD and EC and adopted by EU countries.

\section{References}

1. OECD (2015). Measuring and monitoring BEPS. Action 11 - 2015 Final Report.

2. Beer, S., Mooij, R. A., Liu, L. (2018). International corporate tax avoidance: A review of the channels, magnitudes, and blind spots. IMF Working Papers, 18(168). 
3. Heckemeyer, J. H., Overesch, M. (2013). Multinationals' profit response to tax differentials: Effect size and shifting channels. Discussion paper No. 13-045. ZEW.

4. Clausing, K. A., (2003). Tax-motivated transfer pricing and US intrafirm trade prices. Journal of Public Economics, 87(9), 2207-2223.

5. Kundelis. E., Legenzova, R. (2019). Assessing impact of base erosion and profit shifting on performance of subsidiaries of multinational corporations in Baltic countries. Equilibrium. Quarterly Journal of Economics and Economic Policy, 14(2), 277-293.

6. Hines, J.R., Jr., Rice, E.M. (1994). Fiscal paradise: Foreign tax havens and American business. Quarterly Journal of Economics, 86, 1076-1094.

7. AGrubert, H., Mutti, J. (1991). Taxes, tariffs and transfer pricing in multinational corporate decision making. Review of Economics and Statistics, 73(2).

8. Huizinga, H., Laeven, L. (2008). International profit shifting within multinationals: A multi-country perspective. Journal of Public Economics, 92(5-6).

9. Clausing, K. A. (2009). Multinational firm tax avoidance and tax policy. National Tax Journal, 62(4), 703-725.

10. Loretz, S., Mokkas, S. (2011). Evidence for profit shifting with tax sensitive capital stocks. FinanzArchiv: Public Finance Analysis, 71(1).

11. Lohse, T., Riedel, N. (2013). Do transfer pricing laws limit international income shifting? Evidence from European Multinationals. CESifo Working Paper 4404.

12. Hines, J. R. (2014). How serious is the problem of base erosion and profit shifting? Canadian Tax Journal, 62(2).

13. Rego, S. O. (2003). Tax-Avoidance Activities of U.S. Multinational Corporations. Contemporary Accounting Research, 20(4), 805-833. 